\title{
"Impact of relative and absolute financial risks on share prices: a Zimbabwe Stock Exchange perspective"
}

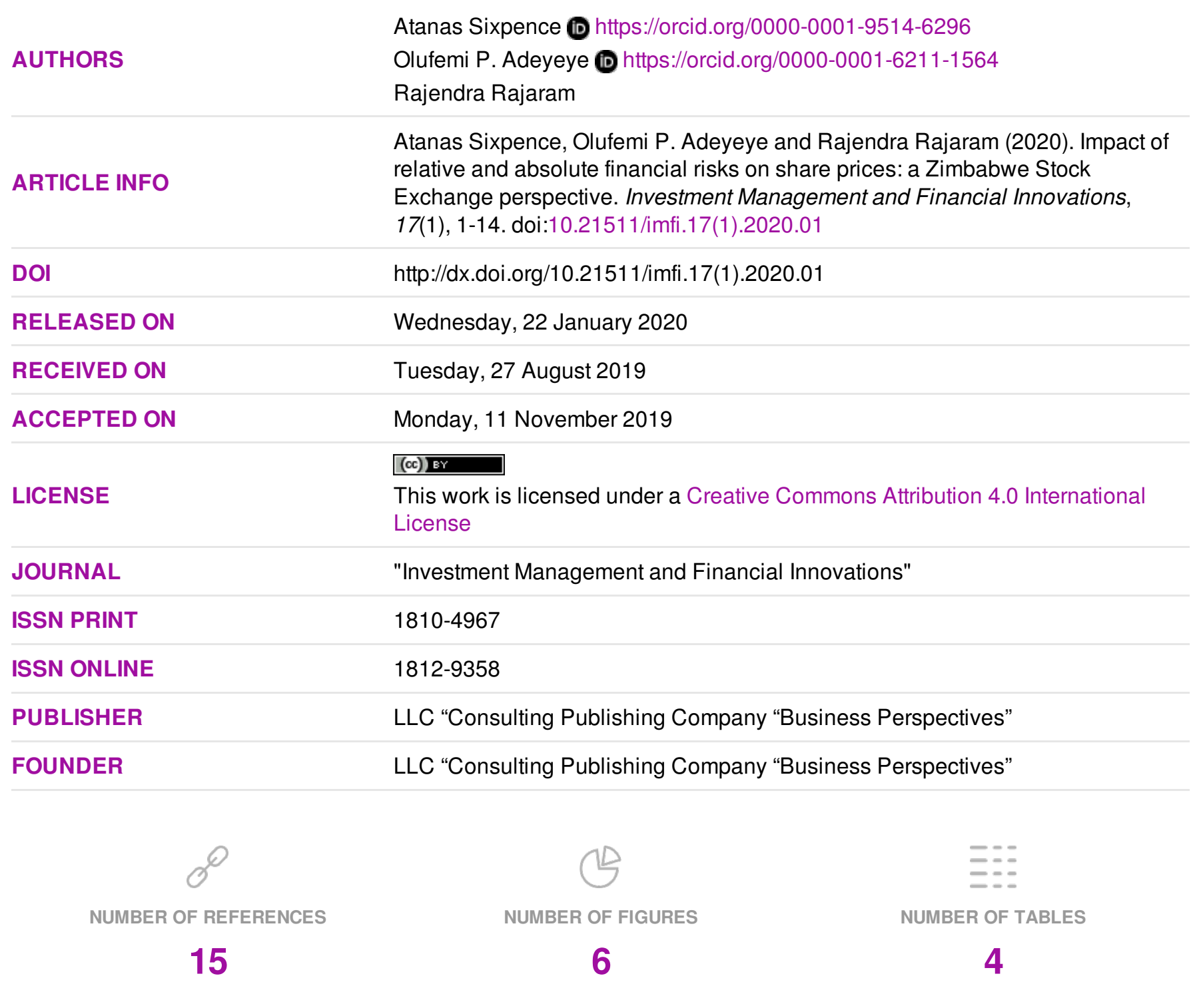

(c) The author(s) 2022. This publication is an open access article. 


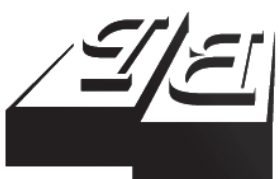

BUSINESS PERSPECTIVES

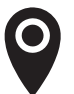

LLC "CPC "Business Perspectives" Hryhorii Skovoroda lane, 10, Sumy, 40022, Ukraine

www.businessperspectives.org

Received on: $27^{\text {th }}$ of August, 2019 Accepted on: $11^{\text {th }}$ of November, 2019

(C) Atanas Sixpence, Olufemi P. Adeyeye, Rajendra Rajaram, 2019

Atanas Sixpence, Ph.D. Candidate, School of Accounting, Economics and Finance, University of KwaZuluNatal, Durban, South Africa.

Olufemi P. Adeyeye, Ph.D. in Banking and Finance, Lecturer and Head of Department, Department of Banking and Finance, Federal University, OyeEkiti, Nigeria.

Rajendra Rajaram, Ph.D. in Accounting, Senior Lecturer and Academic Leader in Managerial Accounting and Financial Management, School of Accounting, Economics and Finance, University of KwaZulu-Natal, Durban, South Africa.

\section{(ㄷ) (i)}

This is an Open Access article, distributed under the terms of the Creative Commons Attribution 4.0 International license, which permits unrestricted re-use, distribution, and reproduction in any medium, provided the original work is properly cited.
Atanas Sixpence (South Africa), Olufemi P. Adeyeye (Nigeria),

Rajendra Rajaram (South Africa)

\section{IMPACT OF RELATIVE AND ABSOLUTE FINANCIAL RISKS ON SHARE PRICES: A ZIMBABWE STOCK EXCHANGE PERSPECTIVE}

\begin{abstract}
The impact of financial risks on share prices concerns investors, company executives and accounting standards developers. Investors need this information in delineating their equity valuation models while company executives need the information to make appropriate capital structure decisions. Accounting standards developers use this information in their policy to make accounting standards contemporary.

The authors examine the link between relative and absolute financial risks and share prices using a dynamic panel of non-financial listed companies on the Zimbabwe Stock Exchange after dollarization. Equity investors incurred losses before dollarization, which prompted this investigation into the sphere of financial risks in order to explain share price movements so that investors can use it to minimize losses in the future. Absolute financial risk is measured by the total debt, while debt/equity ratio measures relative financial risk. Market capitalization as a proxy for equity and debt is measured by total liabilities. An average debt/equity ratio greater or equal to one qualifies a firm into the high-risk category while ratios below one imply low-risk firms. Results from two-step System Generalised Method of Moments (GMM) show negative and significant connection between relative risk and share prices across risk categories. The impact of absolute risk on share prices differs by risk category. Firm managers are advised to keep total liabilities below market capitalization in order to enjoy the benefits of low-risk categorization. Debt ratio is a reasonable indicator of value and investors can use it in equity valuation. Mandatory reporting of debt ratios should be considered by accounting standards developers.
\end{abstract}

\section{Keywords relative financial risk, absolute financial risk, comparative analysis, dynamic panel, value relevance, Zimbabwe Stock Exchange}

\section{JEL Classification $\quad$ C23, M49, G15}

\section{INTRODUCTION}

Analysis of the impact of financial statement variables on share prices falls into the broad category of value relevance research. There is a myriad of financial statement variables focusing on areas such as profitability, cash flows, financial risk and financial position. Since Ball and Brown's (1968) ground-breaking work, value relevance research has gained much traction over the last decades. The major driver of researchers' interest in this strand of research is the desire to uncover financial statement variables that have a relationship with share prices or firm value in order to help investors in firm valuation. It helps investors in the sense that they will be able to focus on only those variables that are linked to share prices. Such variables are said to be value relevant.

Financial risk focuses on debt levels in a firm's capital structure. Although debt is desirable, interest payments on debt are contractual as opposed to dividend payments on common equity. This, therefore, 
means that failure to repay loan principal and/or interest may ultimately lead to a firm being liquidated if reconstruction fails. On the other hand, a firm can go on for several years without declaring any dividend and it will not face similar consequences as those for failing to repay loans. Failure to repay debt poses a threat to a firm's going concern status. Due to these reasons, it is not inconceivable to hypothesize that financial risk should be related to share prices.

The Zimbabwean economic landscape took a dramatic turn from 2009 when a government of national unity was ushered in. Before 2009, there was hyperinflation and investors lost confidence in stock market investments. Listed companies closed and investors lost money on their equity investments. After dollarization in 2009, there was relative stability and growth. Considering the documented risk-return trade-off, a question that arises from the Zimbabwean situation is: can financial risk be useful in determining share prices to avoid the losses suffered prior to dollarization? This research seeks to determine the link between absolute and relative financial risks and share prices for high-risk and low-risk firms listed on the Zimbabwe Stock Exchange (ZSE) between 2010 and 2017. The year 2010 was chosen because it marks the first full year of dollarization. The end date follows from the fact that when the research was done, financial statement data were available only up to the end of 2017.

The study is important because it informs company managers about the impact of their capital structure decisions on the firms' value. The study is significant for the investors as it reveals the significance (or lack of it) of financial risk in firm valuation. There may be no need to focus on variables that are not linked to firm value during equity valuation. This saves the analyst's time and also improves efficiency. Accounting standards developers may also tap into this knowledge to ensure that financial statements continue to be relevant to all stakeholders.

\section{LITERATURE REVIEW}

Financial risk as measured by the amount of debt that a firm carries is part of the broader capital structure decisions that firm managers make, i.e., how much debt and equity should a firm have. Capital structure theories include the pecking order theory, the signalling theory, market timing theory, trade-off theories and the Modigliani and Miller's (1958) theory (hereafter called MM). Of these theories, the MM theory relates to value relevance of financial risk (debt). According to MM's capital structure irrelevance theory, firm value is not dependent on its capital structure, but rather it is contingent upon its real assets. This hinges on a fundamental assumption of there being no taxes. This proposition implies that financial risk is not value relevant: being high-risk or low-risk has no bearing on the value of the firm. MM, however, later acknowledged that where there are market imperfections and taxes, there is a connection between firm value and capital structure (Modigliani \& Miller, 1963). Considering that the real world is replete with imperfections, that is a motivation to empirically test MM's assertions. The pecking order theory (credited to Myers \& Majluf, 1984 and
Myers, 1984) has some contextual relevance to this research in the sense that the issuance of debt will be viewed by the market as signaling undervaluation of equity. Signaling was first coined by Ross (1977). This holds due to information asymmetry, where firm management has information that investors don't have, and this should then lead to value relevance of debt. The rationale for value relevance is that the decision to use or not to use debt will be viewed by the market as a signal of the fortunes of the company going forward, which should lead to investors either buying or disposing of the firm's shares (in line with the perceived fortunes), hence value relevance.

A myriad of empirical studies has been done to determine the impact of a firm's financing options on a firm's value. Gupta, Kumar, and Verma (2016) studied the link between firm value (dependent variable) and operating and financial leverage in Indian manufacturing firms. The study used price/earnings ratio to measure firm value and OLS regression was used to model the relationship. While operating leverage had a negative and statistically significant link with firm value, financial leverage had a statistically insignificant link with 
firm value. This means that the amount of debt in a firm does not influence firm value. These findings render support to the MM proposition that capital structure does not affect firm value. Ogbulu and Emeni (2012) used OLS regression to model the effect of capital structure on firm value in Nigeria based on a random selection of 124 Nigeria Stock Exchange-listed firms. The study hypothesized that firm value is a function of equity and longterm debt. Contrary to what Gupta, Kumar, and Verma (2016) found out, Ogbulu and Emeni (2012) found that long-term debt determines firm value. Equity was found not to have an influence on firm value. While their findings contradict the capital structure irrelevance theory by MM, they render support to the pecking order theory. A different dimension on the Nigeria Stock Exchange-listed firms was given by Enekwe, Agu, and Eziedo (2014). They focused on the effect of financial leverage on firm performance of three pharmaceutical firms between 2001 and 2012. Measures of financial leverage used are debt/equity ratio and interest coverage ratio. Financial performance was measured by return on assets. While other researchers used firm value, Enekwe, Agu, and Eziedo (2014) used firm performance. They did not uncover any meaningful relationship between firm financial performance and the two financial leverage measures. These findings contradict what Ogbulu and Emeni (2012) found out. It is, however, worthwhile to highlight that the two sets of studies' models may not be comparable because their dependent variables, firm value (Ogbulu \& Emeni, 2012) and return on assets (Enekwe, Agu, \& Eziedo, 2014), measure different aspects of the firm. This makes a direct comparison problematic. There are differences among capital structure theories as well as differences in empirical findings on the nexus between the value of the firm and how it finances its operations. The diversity of findings points to the need for more research in this area, especially in Zimbabwe where such research is scant.

A study on the link between financial risk and firm value (among other variables) in Brazil by Caldeira and Loncan (2014) concluded that "short-term and long-term debt had negative marginal effects on the firm value, suggesting a risk-averse behavior of investors in relation to debt" (p. 46). Their research focused on the years 2002 to 2012, utilizing an unbalanced panel of all firms quoted on the Brazilian equities market, excluding financial institutions. The implication of their findings is that where a firm is deemed high-risk, the value of the firm declines and where a firm is categorized as low-risk, firm value increases when it adds more debt. IoanBogdan Robu, Mihaela-Alina, Robu, Mironiuc and Balu (2014) investigated value relevance of distress risk in Romania. Distress risk is, in a way, related to financial risk, where it manifests itself as loan and bond defaults, insolvency and bankruptcy among other indicators. The results showed significant differences in the means of distressed and healthy companies. These studies largely use static models, missing out on the dynamics of share price movements noted by Sixpence and Adeyeye (2018). While the studies reviewed so far use regression analysis of one form or another, Obaidat (2016) adopted a different approach, using questionnaires to determine which accounting information attracts investors' attention on the Amman Stock Exchange. This approach complements the purely empirical analysis of financial statements by capturing what investors actually consider. This can then be compared with what empirical analysis finds. Although the methodology is different, the study still fits into the value relevance of financial statement information strand. Financial risk came up as the variable of most interest to investors on the Amman Stock Exchange.

\section{METHODOLOGY}

\subsection{The model}

Financial risk is measured by the debt/equity ratio and the total amount of debt. Two measures of financial risk are used to determine if investors consider the debt ratio, the absolute debt amount, or both. The research thus considers both relative risk (debt/equity ratio) and absolute risk (total debt). From literature reviewed, debt ratio is the traditional risk measure and we have added total debt to the model, which is a novelty of this study. Total debt is added in order to determine share prices' response to total indebtedness without equity size consideration. Use of a dynamic model is motivated by Onali and Ginesti (2015) who found that adding the first lag of the dependent variable 
(share price) as an explanatory variable enhances the performance of the model. The dynamic model used to determine whether or not financial risk is value relevant is as follows:

$$
\begin{aligned}
& \ln P_{i t}=\beta_{0}+\varphi \ln P_{i, t-1}+\beta_{1} D E_{i t}+ \\
& +\beta_{2} D E_{i, t-1}+\beta_{3} \ln T D_{i t}+ \\
& +\beta_{4} \ln T D_{i, t-1}+\varepsilon_{i t},
\end{aligned}
$$

where $\ln P_{i t}$ - the logarithm of equity price, $\ln P_{i, t-1}$ - the logarithm of equity price in the previous period, $D E_{i t}$ and $D E_{i, t-1}-$ debt/equity ratio and its first lag, respectively, $\ln T D_{i t}$ and $\ln T D_{i, t-1}$ - natural logarithm of total debt and its first lag, respectively, $\varepsilon_{i t}$ the error term.

Two nested models are derived from the main model above. The study employs market capitalization to measure the value of equity, and total debt is given by total liabilities. Total debt includes both current and non-current liabilities in order to capture total indebtedness of a firm (and not just long-term loans). Market capitalization is a proxy for equity because it provides an up-to-date market-related way of viewing firm value, culminating from the actions of numerous stock market players.

\subsection{Model assumptions}

The model assumes:

- a linear relationship between share prices and total debt;

- a linear relationship between share prices and debt ratio;

- the first lag of share price is predetermined. According to Roodman (2009), if using xtabond2 command in Stata, such variables have to be instrumented GMM-style;

- debt/equity ratio and total debt are exogenous. Such variables are entered instrumental variable (IV)-style in xtabond2 (Roodman, 2009). Use of additional instruments enhances efficiency of the model. To achieve this, book value was used as an additional IV-style instru- ment. Book value was added as an instrument because it is the residual value of a firm in cases of liquidation. Creditors and shareholders are paid from this residual value, meaning that for a leveraged firm, book value has to be a good candidate as an additional instrument;

- no autocorrelation in idiosyncratic errors across individuals. Time dummies are thus included to enhance this assumption (Roodman, 2009).

\subsection{Hypotheses development}

In a world with corporate taxes, debt is deemed to be a cheaper source of firm financing than equity (according to MM's proposition). This is because interest payments on debt offer a tax shield, which is not offered by dividend payments on equity. However, debt repayments can be a strain on a firm's cash flows if debt reaches very high levels. This, therefore, suggests existence of an optimal debt ratio, although the actual level is not widely accepted. If we acknowledge that debt is cheaper than equity, it means there should be a link between firm value and debt ratio and this is the basis of Hypothesis 1.

While the level of debt/equity ratio offers a measure of risk that is relative to the size of the entity's equity, one may question the role played by the absolute debt level as measured by total debt. This approach interrogates the thought process of investors: is it possible that investors can be swayed, negatively or positively, by the absolute level of debt? Such an interrogation proposes that investors and analysts can form an opinion of the firm's risk levels by analyzing the level of total indebtedness irrespective of the firm's equity value. This argument, in short, says investors consider absolute risk (measured by total debt) and not relative risk (measured by debt/equity ratio). This informs the second hypothesis. The research thus tested the following two hypotheses:

H1: Relative risk (debt/equity ratio) has an influence on share prices.

H2: Absolute risk (total debt) influences share price movements. 


\section{DATA AND SAMPLES}

\subsection{Data}

Data used in this research comprise of share prices and financial statement variables for the period from 2010 to 2017. Share prices were drawn from the Zimbabwe Stock Exchange price sheets. Audited financial statements were downloaded from the firms' websites. Where this did not cover the entire period under study, the remaining statements were sought from the respective firms' transfer secretaries. Nonavailability of some financial statements from both the firms' websites and transfer secretaries led to these firms being dropped from the study, resulting in 27 out of around 60 ZSE-listed firms being sampled. Financial statements preparation in Zimbabwe is governed by International Financial Reporting Standards (IFRS). While auditing is not a guarantee that financial statements are accurate, it is certainly a sufficient safeguard that enhances reliability of financial statements. Financial firms were excluded because by the nature of their trade, they are highly geared and this will distort debt ratios in this study. Their financial reporting also follows separate guidelines by the regulator.

\subsection{Study samples}

The following samples are utilized:

- the full sample;

- firms with an average debt/equity ratio that is less than one (low-risk);

- firms with an average debt/equity ratio greater than or equal to one (high-risk).

\section{RESULTS}

\subsection{Descriptive statistics}

Table 1 shows the research data's descriptive statistics (on raw data).
Table 1 shows descriptive statistics on raw data covering the variables of the model together with the instrumental variable used (book value). There are 216 observations for all the variables (from 27 firms over 8 years). There is reasonable variation across all four variables judging by their respective standard deviations (SD). However, there is at least one outlier for the variable debt/equity ratio as shown by the distance between the mean and the minimum and maximum values for the variable. This illustrates the extent of indebtedness obtaining on some ZSE-listed firms. Figure 5 in Appendix graphically shows two outliers. Considering that this is the variable of most interest, it is informative to keep the outliers rather than dropping them from the analysis. Based on all the statistics measured, the model is suitable for the dataset.

\subsection{Correlations}

Analyzing the correlations helps to show the relationship between dependent and explanatory variables, and the strength of the relationship. It also helps as an indicator of potential collinearity problems where the independent variables have very high correlation coefficients of more than 0.8 . Table 2 presents the correlations and the $p$-values for levels of significance between the variables. A 5\% significance level was used, and an asterisk on the correlation coefficient indicates statistical significance.

Financial risk, which is at the core of this investigation, is measured by total debt and debt/equity ratio. The two risk measures are the independent variables while share price is the dependent variable. As expected, a negative relationship exists between share price and debt/equity ratio. The relationship is statistically significant, although the association is not that strong (-0.3428). Average debt ratio has an even weaker relationship with share price. This is expected because this is an average over an eightyear period, where some firms have relatively very low debt/equity ratios. The ratio is a constant over the eight-year period while share prices change.

Table 1. Descriptive statistics

\begin{tabular}{|c|c|c|c|c|c|c|}
\hline Variables & $\mathbf{N}$ & Sum & Mean & SD & Minimum & Maximum \\
\hline Share price & 216 & 227.3 & 1.052 & 3.875 & $1.00 \mathrm{e}-04$ & 36 \\
\hline Book value & 216 & $3.334 \mathrm{e}+10$ & $1.543 e+08$ & $5.764 e+08$ & $-2.977 e+06$ & $7.471 e+09$ \\
\hline Total debt & 216 & $7.629 e+10$ & $3.532 e+08$ & $1.592 \mathrm{e}+09$ & 527,400 & $1.283 e+10$ \\
\hline Debt/equity ratio & 216 & 713.6 & 3.304 & 12.05 & 0.00105 & 146.2 \\
\hline
\end{tabular}


Table 2. Correlation matrix

\begin{tabular}{|c|c|c|c|c|c|}
\hline Variables & Share price & Total debt & Book value & Debt/Equity ratio & Average debt ratio \\
\hline Share price & 1.0000 & - & - & - & - \\
\hline \multirow{2}{*}{ Total debt } & $0.6028^{*}$ & 1.0000 & - & - & - \\
\hline & 0.0000 & - & - & - & - \\
\hline \multirow{2}{*}{ Book value } & $0.6193 *$ & $0.6975^{*}$ & 1.0000 & - & - \\
\hline & 0.0000 & 0.0000 & - & - & - \\
\hline \multirow{2}{*}{ Debt/Equity ratio } & $-0.3428^{*}$ & 0.0157 & $-0.2022^{*}$ & 1.0000 & - \\
\hline & 0.0000 & 0.8180 & 0.0030 & - & - \\
\hline \multirow{2}{*}{ Average debt ratio } & $-0.3321^{*}$ & 0.0114 & $-0.2677^{*}$ & $0.4634^{*}$ & 1.0000 \\
\hline & 0.0000 & 0.8681 & 0.0001 & 0.0000 & - \\
\hline
\end{tabular}

This, therefore, affects the strength of the relationship. However, this is of no consequence because average debt ratio is only used to classify companies into low-risk and high-risk categories, it is neither a regression variable nor an instrumental variable. Total debt has a much stronger and significant relationship with share price but, contrary to expectations, the relationship is positive. In this study, total debt is obtained by adding current liabilities to non-current liabilities. This points to the fact that current liabilities outweigh non-current liabilities. Current liabilities are normally directly related to operating activity in a company: the higher the activity, the higher the current liabilities. Examples of current liabilities that are directly related to operating activity in a company include trade payables, value-added tax, corporate tax, and utility bills. Analyzing the firms' financial statements shows that many of them do not have longterm debt, but they do have current liabilities. This helps explain the positive association that exists between share price and total debt. Chances of collinearity between the two independent variables is very low, with an insignificant correlation of 0.0157 between total debt and debt/equity ratio. The instrumental variable book value is strongly associated with share price.

\subsection{Distribution of residuals}

The study sample is divided according to each firm's average debt/equity ratio, where firms with an average debt/equity ratio greater than or equal to one are categorized under high-risk firms and those with average debt ratios less than one fall into the low-risk class. The models were run along these lines, residuals predicted and histograms were used to visualise the distributions. Figures 1 and 2 in Appendix show the histograms for highrisk firms and low-risk firms, respectively. The re- siduals are not an exact normal distribution but they are not a very bad approximation of the normal distribution. Since there is no strict requirement for normality in such a regression, no bias is expected judging by the normality test results. The dynamic model stated earlier is therefore appropriate for this study.

\subsection{Linearity tests}

A linear dynamic model is employed to determine value relevance of financial risk for firms listed on the ZSE. It is thus worthwhile to check whether the relationship between dependent and explanatory variables is linear or not. Figures 3 and 4 in Appendix depict the association between the dependent variable and debt/equity ratio for both samples. A negative linear association exists between the dependent variable and debt/equity ratio in both samples. A linear model is thus appropriate. The association between dependent variable and total debt is positive in both samples. This corroborates what the correlation matrix showed earlier. Given that the relationship is linear, a dynamic linear model can thus be used to examine the association between share price and total debt.

\subsection{Regression results}

Table 3 and Table 4 show regression output and diagnostic test results for the full sample and the two sub-samples, respectively.

Model 1 is the base model and Models 2 and 3 emanate from dropping one variable at a time in order to check robustness of results to dropping a variable. According to the $F$-test, all models are significant at $1 \%$ level, meaning that the variables explain movement in share prices. The instrument matrix was collapsed to limit the number of in- 
Table 3. Full sample regression results

\begin{tabular}{|c|c|c|c|}
\hline \multirow{2}{*}{ Variables } & Model 1 & Model 2 & Model 3 \\
\hline & Log Share price & Log Share price & Log Share price \\
\hline \multirow{2}{*}{ Log of Lag share price } & $1.073 * * *$ & $1.003 * * *$ & $0.974 * * *$ \\
\hline & $(0.088)$ & $(0.213)$ & $(0.023)$ \\
\hline \multirow{2}{*}{ Log total debt } & 0.048 & 0.041 & $-\ldots$ \\
\hline & $(0.112)$ & $(0.157)$ & - \\
\hline \multirow{2}{*}{ Log of Lag total debt } & $-0.161^{*}$ & -0.118 & - . \\
\hline & $(0.081)$ & $(0.133)$ & $--\ldots$ \\
\hline \multirow{2}{*}{ Debt/Equity ratio } & $-0.031^{* * *}$ & $-\ldots$ & $-0.032 * * *$ \\
\hline & $(0.004)$ & - & $(0.004)$ \\
\hline \multirow{2}{*}{ Lag of debt/equity ratio } & $0.041^{* * *}$ & -... & $0.034 * * *$ \\
\hline & $(0.009)$ & $-\ldots$ & $(0.005)$ \\
\hline \multirow{2}{*}{ Constant } & 2.142 & 1.468 & -0.034 \\
\hline & $(1.584)$ & $(3.333)$ & $(0.210)$ \\
\hline Number of instruments & 13 & 11 & 11 \\
\hline Observations & 189 & 189 & 189 \\
\hline Number of firms & 27 & 27 & 27 \\
\hline Arellano-Bond test for $A R(1)$ & -2.46 & -1.54 & -2.63 \\
\hline$P$-value AR(1) & 0.014 & 0.123 & 0.008 \\
\hline Arellano-Bond test for $\mathrm{AR}(2)$ & -1.11 & 0.89 & -0.99 \\
\hline$P$-value AR(2) & 0.265 & 0.373 & 0.322 \\
\hline Hansen test statistic & 0.91 & 3.06 & 0.17 \\
\hline$P$-value Hansen test & 0.340 & 0.080 & 0.681 \\
\hline
\end{tabular}

Notes: Standard errors are in parentheses. $\mathrm{AR}(\mathrm{K})$ is the test for the Kth order autocorrelation, ${ }^{* * *}, * *$ and * represent statistical significance at the $1 \%, 5 \%$ and $10 \%$ levels.

struments used, resulting in 13 instruments for Model 1 and 11 instruments for Models 2 and 3. In all cases, the number of observations (189) exceeds the number of instruments used, meaning there is no problem of too many instruments.

Models 1 and 2 show a positive but statistically insignificant relationship between share prices and total debt. The coefficient of total debt is 0.048 in Model 1 , which changes to 0.041 when debt/equity ratio is dropped from the regression. Windmeijer corrected standard errors register small changes between the two models. Models 1 and 3 show that there is a negative relationship between share price and debt/equity ratio, which is in line with the correlation results. The relationship is statistically significant at $1 \%$ level and this shows that an increase in the debt ratio reduces share prices. The coefficient of debt/equity ratio barely changes when total debt is dropped from the regression. Standard errors are very low and they do not change when total debt is dropped. This shows that the model is robust.

The Arellano-Bond test for autocorrelation shows that there is no autocorrelation in the models because the $p$-values for second-order autocorrelation [AR (2)] are greater than 0.05 in all models. The Hansen test shows that the instruments used in the models are valid.

Results for both low-risk and high-risk firms are presented next.

Table 4. Regression results for sub-samples

\begin{tabular}{|c|c|c|c|c|c|c|}
\hline \multirow{3}{*}{ Variables } & \multicolumn{3}{|c|}{ Low-Risk Firms } & \multicolumn{3}{|c|}{ High-Risk Firms } \\
\hline & Model 1 & Model 2 & Model 3 & Model 4 & Model 5 & Model 6 \\
\hline & Log S.P. & Log S.P. & Log S.P. & Log S.P. & Log S.P. & Log S.P. \\
\hline \multirow{2}{*}{ Log of Lag share price } & $0.882 * * *$ & $0.682 * * *$ & $0.918^{* * *}$ & $1.092^{* * *}$ & 0.956 & $0.974 * * *$ \\
\hline & $(0.082)$ & $(0.144)$ & $(0.070)$ & $(0.213)$ & $(0.633)$ & $(0.042)$ \\
\hline \multirow{2}{*}{ Log total debt } & $0.346 * * *$ & 0.080 & - & 0.125 & 0.398 & - \\
\hline & $(0.068)$ & $(0.095)$ & - & $(0.401)$ & $(0.666)$ & - \\
\hline \multirow{2}{*}{ Log of Lag total debt } & $-0.289 * * *$ & 0.067 & - & -0.257 & -0.415 & - \\
\hline & $(0.090)$ & $(0.091)$ & - & $(0.280)$ & $(0.348)$ & - \\
\hline \multirow{2}{*}{ Debt/equity ratio } & $-1.689 * * *$ & - & $-0.980 * * *$ & $-0.028 * * *$ & - & $-0.029 * * *$ \\
\hline & $(0.220)$ & - & $(0.234)$ & $(0.005)$ & - & $(0.006)$ \\
\hline
\end{tabular}


Table 4 (cont.). Regression results for sub-samples

\begin{tabular}{|c|c|c|c|c|c|c|}
\hline \multirow{3}{*}{ Variables } & \multicolumn{3}{|c|}{ Low-Risk Firms } & \multicolumn{3}{|c|}{ High-Risk Firms } \\
\hline & Model 1 & Model 2 & Model 3 & Model 4 & Model 5 & Model 6 \\
\hline & Log S.P. & Log S.P. & Log S.P. & Log S.P. & Log S.P. & Log S.P. \\
\hline \multirow{2}{*}{ Lag of debt/equity ratio } & $1.598^{* * *}$ & - & $0.751 * *$ & $0.036 * *$ & - & $0.032 * * *$ \\
\hline & $(0.311)$ & - & $(0.285)$ & $(0.012)$ & - & $(0.008)$ \\
\hline \multirow{2}{*}{ Constant } & -1.132 & -3.334 & -0.369 & 2.668 & 0.326 & 0.071 \\
\hline & $(1.036)$ & $(2.350)$ & $(0.286)$ & $(4.143)$ & $(13.359)$ & $(0.435)$ \\
\hline Number of instruments & 13 & 11 & 11 & 13 & 11 & 11 \\
\hline Observations & 98 & 98 & 98 & 88 & 88 & 88 \\
\hline Number of firms & 14 & 14 & 14 & 13 & 13 & 13 \\
\hline Arellano-Bond test for $A R(1)$ & -3.08 & -1.79 & -2.38 & -2.16 & -1.42 & -2.20 \\
\hline$P$-value AR(1) & 0.002 & 0.074 & 0.017 & 0.031 & 0.157 & 0.028 \\
\hline Arellano-Bond test for $\mathrm{AR}(2)$ & -1.40 & -1.07 & -1.93 & -0.07 & 0.96 & -0.32 \\
\hline$P$-value AR(2) & 0.162 & 0.283 & 0.054 & 0.943 & 0.339 & 0.751 \\
\hline Hansen test statistic & 0.42 & 0.04 & 1.26 & 1.07 & 2.67 & 1.35 \\
\hline$P$-value Hansen test & 0.519 & 0.849 & 0.262 & 0.301 & 0.102 & 0.244 \\
\hline
\end{tabular}

Notes: Standard errors are in parentheses. $\mathrm{AR}(\mathrm{K})$ is the test for the Kth order autocorrelation, $* * *, * *$ and $*$ represent statistical significance at the $1 \%, 5 \%$ and $10 \%$ levels.

\subsubsection{Results of low-risk firms}

Models 1, 2 and 3 present results for firms with average debt/equity ratios that are less than one (low-risk firms). Nested models are used to check sensitivity of results to dropping one independent variable at a time. To limit the instrument count, GMM-style instrument matrix was collapsed in all the models. Model 1 has 13 instruments while Models 2 and 3 have 11 instruments. There are 98 observations from 14 low-debt firms. According to the $F$-test, the models are significant at $1 \%$ level.

Models 1 and 2 show that total debt is positively related with share price. The level of significance is however different in the two models: in Model 1 , the significance level is $1 \%$ but in Model 2, it is not significant. Dropping debt/equity ratio causes the significance level to change. The coefficient of total debt is 0.346 in Model 1, changing to 0.080 in Model 2 when debt/equity ratio is left out of the regression. The corrected standard errors are relatively low and within a reasonable range in both cases $(0.068$ and 0.095$)$. This shows that while there is some sensitivity to dropping one variable, the model is relatively stable.

Debt/equity ratio is negatively related with share prices as depicted in Models 1 and 3, and the relationship is statistically significant ( $1 \%$ level). In Model 1, the coefficient of debt/equity ratio is -1.689 , which changes to -0.980 as a result of dropping the variable total debt from the regression. Windmeijer corrected standard errors also change from 0.220 to 0.234 . The changes caused by dropping total debt are relatively small, which attests to a robust model whose results are reliable. These results are consistent with results from the full sample.

\subsubsection{Results of high-risk firms}

Models 4, 5 and 6 represent high-risk firms. Highrisk firms are those with an average debt/equity ratio which is greater than or equal to one. Thirteen firms meet this criteria, giving 88 observations. Model 4 used 13 instruments while the other models used 11 instruments. The number of instruments is less than the number of observations, implying that there is no instrument proliferation problem. The sensitivity of the model results is again checked by dropping one independent variable at a time. The $F$-test shows that all models are significant at $1 \%$ level.

Just like in the low-risk sample, total debt is positively related with share price in Models 4 and 5. In both models, the relationship lacks statistical significance and this is consistent with the full sample results. When compared to the low-risk sample, the results do not exactly match since total debt is significant in Model 1. The coefficient of total debt is 0.125 (Model 4), changing to 0.398 when debt/equity ratio is dropped in Model 5. 
Dropping a variable causes a reasonable change in the coefficients and standard errors of the model, meaning that the model is stable and reliable.

Models 4 and 6 show that a negative relationship exists between share prices and debt/equity ratio. The relationship is significant at $1 \%$ level. All this is consistent with results from both the full sample and the low-risk sample. The debt/equity ratio's coefficient in Model 4 is -0.028 . This changes to -0.029 when total debt is dropped from the regression in Model 6. Windmeijer corrected standard errors, respectively, change from 0.005 to 0.006 . These changes show that the model is immune to one variable being dropped implying that its results are reliable. Mean stationarity test and autocorrelation results are discussed below.

\subsubsection{Model analysis}

We fail to reject the existence of first-order autocorrelation (AR (1)) as measured by the ArellanoBond test in Models 1, 3, 4 and 6. This is expected to happen by construction and it is not informative. We reject both AR (1) in Models 2 and 5 and AR (2) (second-order autocorrelation) in all six models and conclude that there is no autocorrelation in the models. The Hansen test of over-identifying restrictions shows that the instruments used are valid and the models are not weakened by too many instruments. This attests that model results are valid and the findings are reliable.

\section{DISCUSSION OF FINDINGS}

Statistical significance of debt/equity ratio in the full sample means that relative risk is value relevant on the ZSE. On the other hand, total debt is not significant in the full sample and this means that absolute risk is not value relevant. These findings are fully reminiscent of results in the highrisk sample but partly to those in the low-risk sample. The full sample was used largely as a barometer for the two samples being compared to each other.

The variable total debt is value relevant in one of the low-risk firms' models, which goes against the MM proposition that capital structure decisions have no bearing on firm value. For high-risk firms, total debt is not value relevant, thus supporting the MM proposition. This means that, consciously or not, investors on the ZSE tend to react in a way that is unwarranted by the absolute levels of total debt carried by high-risk firms. This overreaction creates a disconnect between share price movements and total debt changes. As total debt increases, share prices disproportionately change as some investors begin to worry about the survival of the firm in question. The fear of losing one's investment may cause a rational investor to behave irrationally in the face of perceived excessive risk. For low-risk firms, this overreaction is non-existent. This feeds into the notion that there is an ideal debt ratio, beyond which debt ceases to be cheaper than equity. Furthermore, a possible reason for lack of value relevance of total debt in high-risk firms is the perceived higher level of risk. There is a possibility that investors may over-punish highly indebted firms by trading them at below intrinsic value, resulting in lack of value relevance of total debt. Investors may be concerned about the huge absolute values of total debt, thus trading the shares at a discount. Another possible reason lies in the composition of total debt; this study used both short-term and long-term liabilities. Lack of statistical significance can be a reflection of the market not paying attention to short-term liabilities which are included in total debt. However, this argument is weakened by the fact that the variable debt/equity ratio is statistically significant, where debt also includes short-term liabilities. The most compelling reason is the existence of a discount on share prices due to perceived high debt levels caused by absolute total debt figures. They maintain this discount regardless of any positive developments on the debt front, as long as the debt ratio is greater than or equal to one, hence the disconnect in debt ratios and share prices. Lack of value relevance of total debt does not necessarily mean the shares are undervalued, there is also a possibility that they are overvalued and are kept that way irrespective of debt ratio movements, hence lack of value relevance. The latter scenario will be in line with the debt signaling theory, where issuance of more debt signals to the market that management is bullish about the future prospects, thus driving up shares beyond their intrinsic values and out of sync with debt ratio changes. Considering that almost all high-debt firms on the ZSE did not perform well during the eight-year study period, this 
assertion is highly unlikely to have been the reason for lack of statistical significance of total debt.

Where a firm is already carrying high levels of debt (average debt/equity ratio greater than one), an increase in debt ceases to have a proportionate increase in share price as would be expected when the average debt/equity ratio is less than one. We hypothesize that there is a high debt illusion that causes investors to put a discount on shares of high-risk firms and maintain that discount regardless of changes in the absolute total debt values up until the average debt/equity ratio falls below one. The high debt illusion is defined here as a situation where a firm has total liabilities that are higher than its market capitalization and the debt is perceived to be too much, leading to undervaluation of its shares. This view of absolute risk (total debt) is illusory in that when the debt is put into firm size context (creating debt/equity ratio), the relative risk measure is now linked to share prices. The implication to company executives is that they should keep their total liabilities (short-term and long-term liabilities) lower than their market capitalization. In this way they would be classified as low-risk firms. The advantage of this classification is that investors will correctly adjust their valuations for any changes in debt levels, unlike when a company is a high-risk firm where there is a disconnect between total liabilities and share price movements. This may affect valuations of rights issues that the company may issue. Undervaluation of shares also negatively affects the firm's shareholders. By having a firm's shares correctly valued by the market, that is another way of maximizing shareholder wealth, which is an integral goal for any for-profit institution. The observed phenomenon across the two risk categories on the variable total debt may be due to herding behavior in the face of excessive risk. Nonetheless, the herding behavior hypothesis needs further research.

All samples show a negative and statistically significant relationship between share price and the debt/equity ratio, i.e., there is no distinction between low-risk and high-risk firms with regards to value relevance of debt/equity ratio. A negative relationship means that a rise in the debt/equity ratio leads to a drop in equity prices because investors become concerned about increased risk levels. This, to a large extent, shows that investors on the ZSE are risk-averse. Regardless of the fact that the debt ratio is less than one (low-risk firms), investors will still track the debt/equity ratio and factor it in their equity valuations. Since the debt ratio used in this study includes short-term liabilities, company executives should be aware that investors cannot be hoodwinked by "hiding" company debts in shortterm debt like bank overdrafts. Custom has it that the debt ratio focuses on long-term debt, which does not capture the added risk from short-term debt distress. Short-term debt distress actually poses a greater risk than long-term debt because of the short time span within which a firm has to raise funds to clear the debts. Investors are therefore justified in taking this risk into consideration when valuing firms. Investors are risk-conscious, keeping track of the debt ratio. It appears that they rely more on the debt ratio (relative risk) than the absolute debt figures (absolute risk) because total debt is value relevant in just one model under low-risk firms. Absolute figures (total debt) do not convey much information if looked at in isolation. Deflating the figures by the relative worth (equity) puts this risk into context: what may appear to be too big a debt figure in absolute terms may turn out to be reasonable if that company's market capitalization (equity) is much larger than the total debt figure. This explains why investors may ignore total debt, hence lack of value relevance, and focus on the more informative debt/equity ratio.

While our findings contradict what Gupta, Kumar, and Verma (2016) found out in India, they support what Ogbulu and Emeni (2012) found out on the Nigerian stock market. Value relevance of absolute risk for low-risk firms is, to a certain extent, in line with the signalling theory by Ross (1977). It does not fully conform with the signalling theory because, while the relationship holds for low-risk firms, it does not hold for high-risk firms since the relationship is not statistically significant. With regard to low-risk firms, an increase in total debt is a good omen to investors, leading to an increase in equity prices. This makes sense because these firms are far from experiencing debt distress which may affect their financial performance. Debt is not yet at unpalatable levels that may affect a firm's going concern status. However, for high-risk firms there is no such good omen. Investors are concerned about such firms' debt distress, which then affects financial performance. This may result in 
bankruptcy of the affected firm. Debt distress also negatively affects a company's ability to exploit profitable ventures in the future because the firm cannot access more debt to make the investment. A low-risk firm, on the other hand, can approach the market for such funding, and this is what causes the market to view low-risk firms favourably.

Results from Ioan-Bogdan Robu, Mihaela-Alina Robu, Mironiuc, and Balu (2014) show that inves- tors consider financial distress as a bad sign when they make decisions on whether they should buy, hold or sell shares. This resonates with the findings in this study in general terms. Obaidat (2016) found that the most value relevant financial information is financial risk (among other accounting statement variables). This supports the findings in this research, where relative financial risk is value relevant. However, the exact measures of financial risk differ.

\section{CONCLUSION}

Debt/equity ratio is value relevant regardless of whether a firm is deemed a low-risk or a high-risk firm. Debt/ equity ratio is more "objective" than total debt because it deflates total liabilities by the total consensus value (yielding relative risk) arising from market participants' actions. This consensus value (market capitalisation) is generally viewed as objective because it is a result of actions of numerous buyers and sellers on the market agreeing on what the company is worth (the share price). The ratio is also easily comparable to other peers, as opposed to total liabilities (absolute risk) which may not be easily comparable if the peers are of different sizes. The fact that it is objective and easily comparable with peers helps to explain why the debt/equity ratio is value relevant across firms of varying debt ratios. Company executives should therefore note that whether they use short-term or long-term debt, the market correctly responds to these forms of debt. Investors are so discerning that they cannot be fooled to think that a firm has low leverage when it uses short-term debt to finance its activities. Accounting standards developers can help investors by putting a requirement that companies should report, in their financial statements, debt ratios that include current and non-current liabilities to make it easier for analysts and investors to do their analyses. This is premised on the realization that debt/ equity ratio as defined in this study is value relevant regardless of whether a company is classified as a low- or high-risk company. This research has provided evidence that support hypothesis 1 for both high-risk and low-risk firms listed on the ZSE: relative risk is value relevant irrespective of risk category. We fail to reject hypothesis 2 for low-risk firms but reject it for high-risk firms: value relevance of absolute risk is contingent upon the risk category of the firm. These are the major contributions of this research to the field of value relevance studies. Furthermore, the novelty of this study also lies in determining the link between total liabilities (instead of long-term debt only) and share prices. Measurement of debt ratios should move away from the traditional focus on long-term debt towards current and non-current liabilities because all these liabilities put a strain on a firm's cash flows.

Future studies can include equity in the model and determine value relevance of two financing options. This will give a complete picture of the value relevance of capital structure decisions because the fact that debt is not value relevant does not mean that equity is value relevant. This total picture will equip firm management with full knowledge of the implications of their capital structure decisions. As highlighted earlier, further studies can also focus on herding behaviour of investors when confronted by high risk levels.

\section{REFERENCES}

1. Ball, R., \& Brown, P. (1968).

An empirical evaluation of accounting income numbers. Journal of Accounting Research, 6(2), 159-178. Retrieved

from https://www.jstor.org/ stable/2490232?seq=1\#page_scan_ tab_contents
2. Enekwe, C. I., Agu, C. I., \& Eziedo, K. N. (2014). The Effect of Financial Leverage on Financial Performance: Evidence of Quoted Pharmaceutical Companies in Nigeria. IOSR Journal of Economics and Finance, 5(3), 17-
25. https://doi.org/10.9790/59330531725

3. Gupta, P. K., Kumar, S., \& Verma, P. (2016). Association between Degree of Leverages and Firm Value. Asian Journal of Finance \& Accounting, 8(1), 212- 
229. http://dx.doi.org/10.5296/ ajfa.v8i1.9455

4. Caldeira, J. F., \& Loncan, T. R. (2014). Capital Structure, Cash Holdings and Firm Value: a Study of Brazilian Listed Firms. Retrieved from https:// papers.ssrn.com/sol3/papers. cfm?abstract_id=2329346

5. Modigliani, F., \& Miller, M. H. (1958). The cost of capital, corporation finance and the theory of investment. The American Economic Review, 49(4), 655-669. Retrieved from https://www.jstor.org/ stable/1812919?seq=1\#page_ scan_tab_contents

6. Modigliani, F., \& Miller, M. H. (1963). Corporate taxes and the cost of capital: A correction. The American Economic Review, 53(3), 433-443. Retrieved from https://www.semanticscholar. org/paper/CORPORATEINCOME-TAXES-AND-THECOST-OF-CAPITAL\%3A-AFranco-Merton/540de3c11df3ea a779407309d7f5b3f2a90a48df

7. Myers, C. S., \& Majluf, S. N. (1984). Corporate financing and investment decisions when firms have information that investors do not have. Journal of Financial Economics, 13(2), 187-221.

https://doi.org/10.1016/0304405X(84)90023-0

8. Myers, C. S. (1984). The capital structure puzzle. Journal of Finance, 39(3), 575-592. https:// doi.org/10.1111/j.1540-6261.1984. tb03646.x

9. Obaidat, A. N. (2016). Accounting Information: Which Information Attracts Investors Attention First? Accounting and Finance Research, 5(3), 107-117. http://dx.doi. org/10.5430/afr.v5n3p107

10. Ogbulu, O. M., \& Emeni, F. K. (2012). Capital Structure and Firm Value: Empirical Evidence from Nigeria. International Journal of Business and Social Science, 3(19), 252-261. Retrieved from http:// www.ijbssnet.com/journals/ Vol_3_No_19_October_2012/29. pdf

11. Onali, E., \& Ginesti, G. (2015). Sins of Omission in Value Relevance Empirical Studies (36 p.). (Munich Personal RePEc Archive MPRA Paper No. 64265). Retrieved from https://mpra. ub.uni-muenchen.de/64265/
12. Robu, Ioan-Bogdan, Robu, Mihaela-Alina, Mironiuc, M., \& Balu, F.O. (2014). The value relevance of financial distress risk in the case of RASDAQ companies. Accounting and Management Information Systems, 13(4), 623-642. Retrieved from https://ideas.repec.org/a/ami/ journl/v13y2014i4p623-642.html

13. Roodman, D. (2009). How to Do xtabond2: An Introduction to "Difference" and "System" GMM in Stata. Stata Journal, 9(1), 86-136. Retrieved from https:// ideas.repec.org/a/tsj/stataj/v9y2009ilp86-136.html

14. Ross, S. A. (1977). The determination of financial structure: The incentive signalling approach. The Bell Journal of Economics, 8(1), 23-40. Retrieved from https://ideas. repec.org/a/rje/bellje/v8y1977ispringp23-40.html

15. Sixpence, A., \& Adeyeye, O. P. (2018). Perception of negative earnings persistence and value relevance: evidence from Zimbabwe. Cogent Economics and Finance, 6(1). https://doi.org/10.10 80/23322039.2018.1559711

\section{APPENDIX A. RESIDUALS AND LINEARITY TEST FIGURES}

\section{Distribution of residuals}

Figures 1 and 2 present the histograms for high- and low-risk firms.

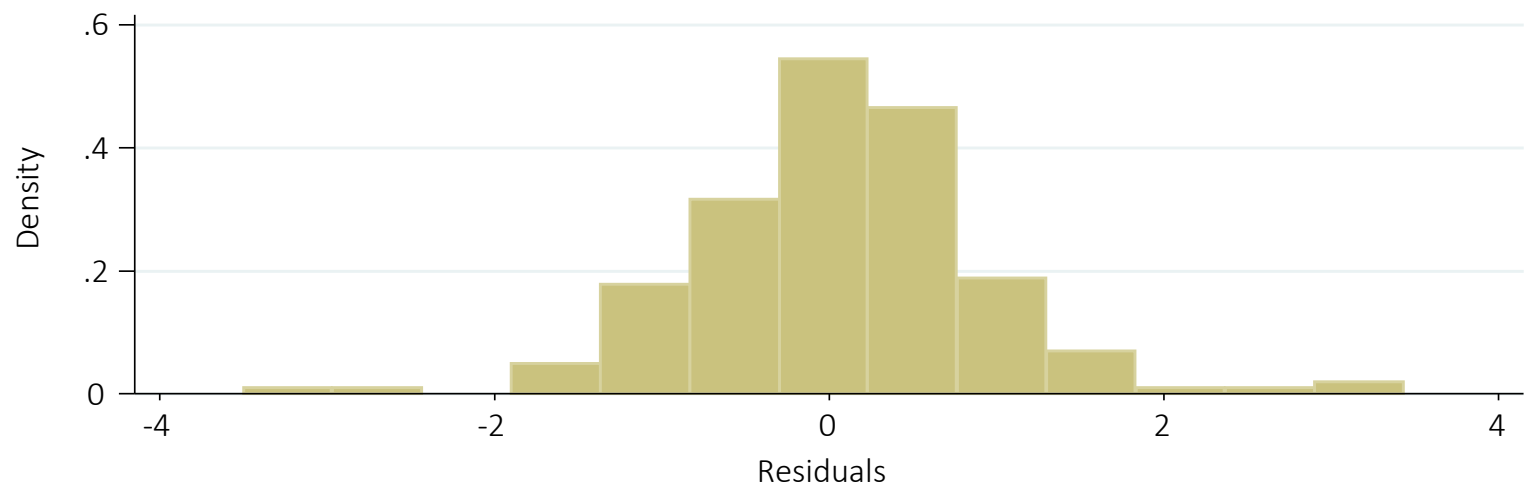

Figure 1. High-risk firms 


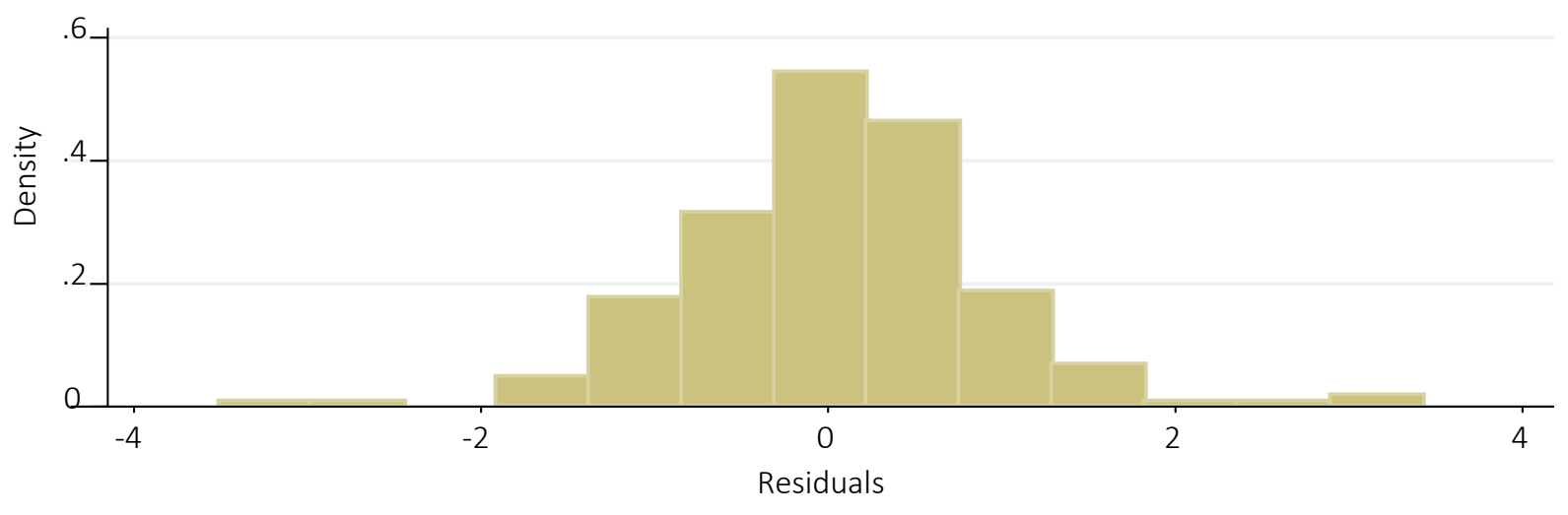

Figure 2. Low-risk firms

\section{Linearity test diagrams}

Figures 3 and 4 depict the relationship between share price and debt ratio as well as share price and total debt for firms whose average debt ratio is less than one (low-risk firms).

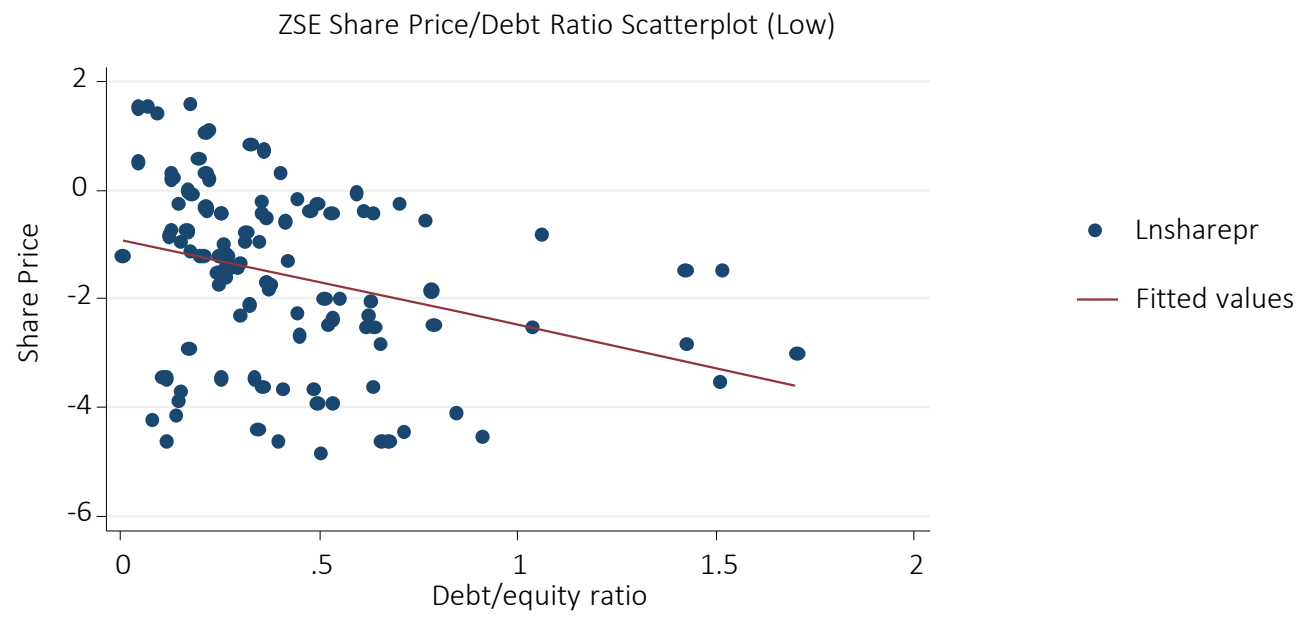

Figure 3. Share price-debt ratio

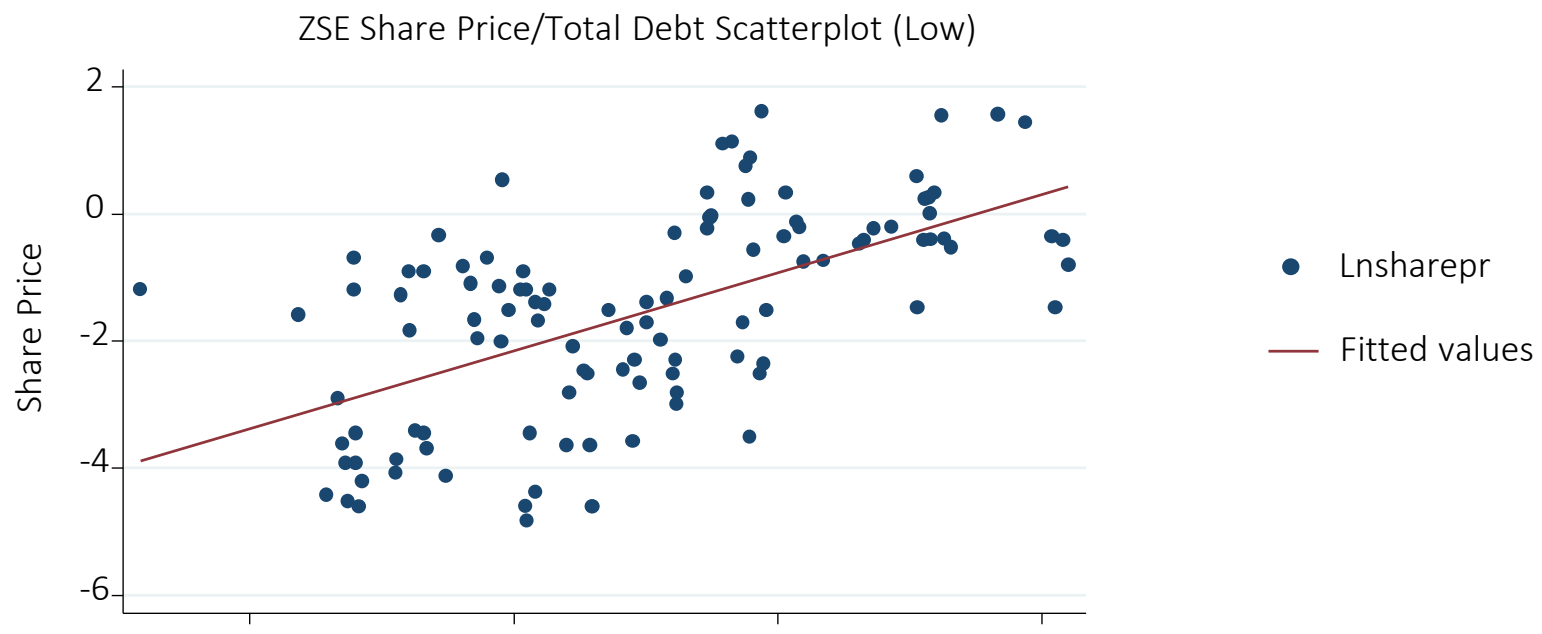

Figure 4. Share price-total debt 
Figures 5 and 6 depict the relationship between share price and debt ratio as well as share price and total debt for firms whose average debt ratio is greater than or equal to one (high-risk firms).

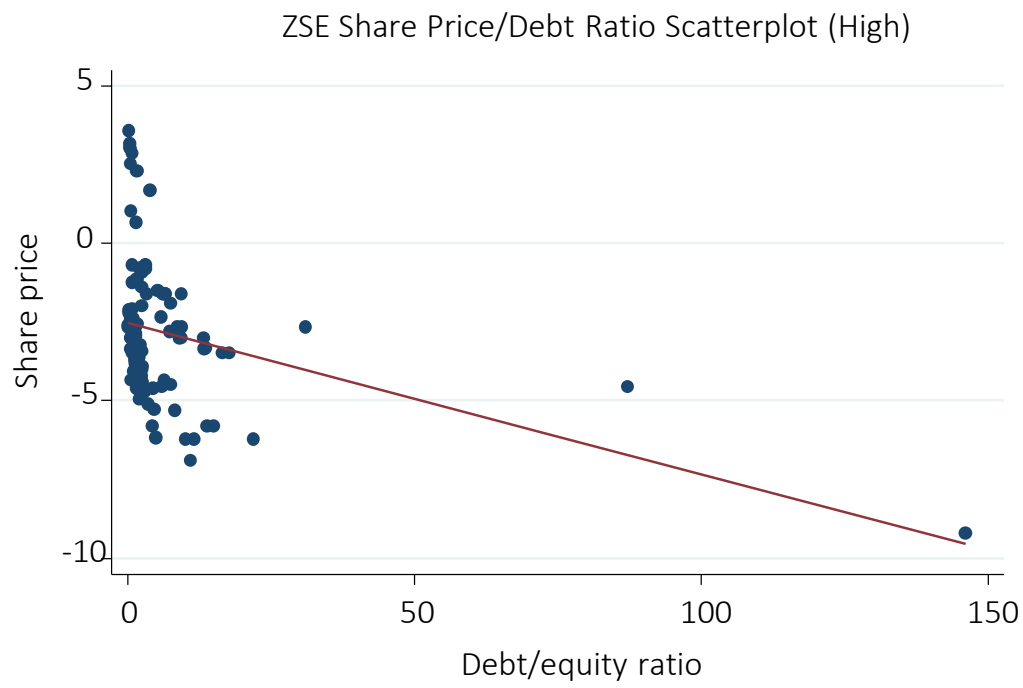

- Lnsharepr

Figure 5. Share price-debt ratio

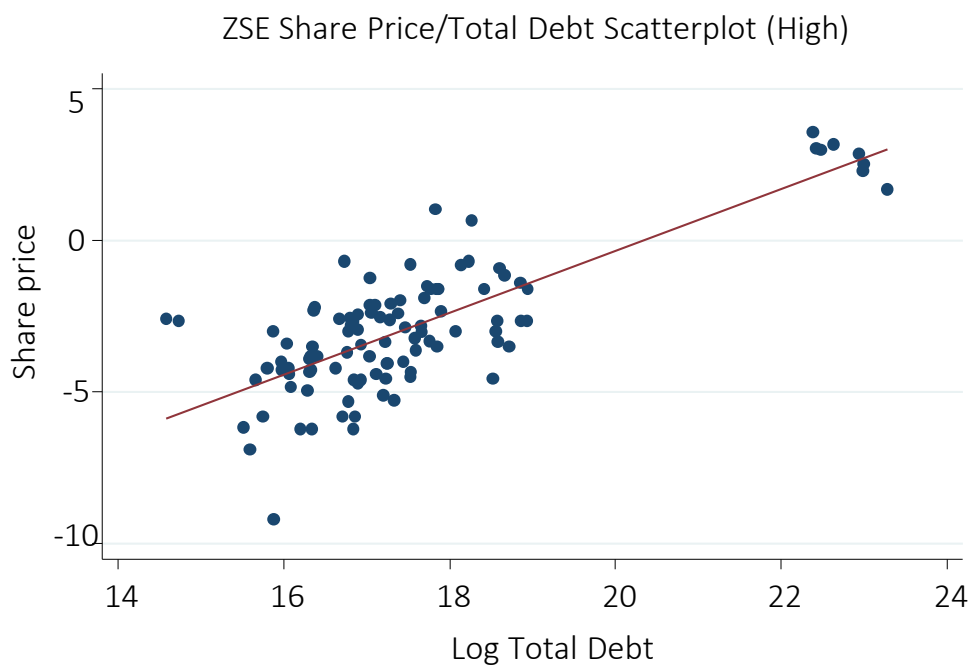

- Lnsharepr

— Fitted values

Figure 6. Share price-total debt 